\title{
Running quality assessment of a passenger car produced in the Republic of Uzbekistan
}

\author{
Dilfuza Zairova*, Mukhammad Ayubkhan Kadirov, Nodirali Khojiev, Farkhod \\ Khikmatov, and Kurbonnazar Shokuchkorov \\ Tashkent State Transport University, Tashkent, Uzbekistan
}

\begin{abstract}
The article discusses a topical issue regarding the replenishment of the passenger car fleet with promising and comfortable passenger cars. To determine the quality assessment of the passenger carriage, a check was carried out for compliance with the standards for the smoothness of the carriage. Based on the main technical parameters of the new passenger carriage, the main calculated values were determined with and without taking into account the payload. Comparing the results obtained with the highest permissible values, it was found that the quality indicators of the passenger carriage model 61-920 manufactured in the Republic of Uzbekistan do not exceed the permissible values and meet the requirements.
\end{abstract}

\section{Introduction}

In railway transport, it is important to prepare coordinated measures for the development of new types of traction, renovation of the car fleet, improvement of the track superstructure, which will ensure high train speeds combined with traffic safety and convenience for passengers [1-4]. The rational use of these funds and the rational organization of transportation work constitute the main content of the operational activities of railway transport [5-6].

The passenger carriage park of Uzbekistan railways is one of the types of railway rolling stock [7-8]. The quality of service and the timeliness of passenger delivery, productivity, and economic performance of railways depend on its technical condition and ability to meet transportation needs [9-11].

To replenish the fleet with promising passenger cars, the designers of the Tashkent Plant for the Construction and Repair of Passenger Cars JSC have designed a new 61-920 model passenger car with a modern air conditioning system [12].

\footnotetext{
* Corresponding author: tytmzairova@yandex.ru
} 
The passenger carriage is an integral part of the passenger railroad complex, providing the demand for railway transport services. Such indicators characterize the criteria for evaluating passenger service as the comfort and smoothness of the carriage [13-15].

When determining the quality assessment of a passenger carriage, it is necessary to check the compliance with the standards for the smoothness of the carriage, provided for by the standard and other normative and technical documentation for cars [16-18].

When designing this passenger car for the railways of Uzbekistan, young scientists of the department "Carriages and carriage facilities" of Tashkent Railway Engineering Institute(TREI), theoretical studies determined the quality indicators of the carriage.

\section{Materials and Methods}

Passenger compartment carriage model 61-920, manufactured following the design documentation 920.00.00.000 developed by Tashkent Plant for the Construction and Repair of Passenger Cars JSC. The main technical parameters of this car are shown in Table 1.

Table 1. Main technical parameters and overall dimensions of a passenger carriage model 61920

\begin{tabular}{|l|c|c|}
\hline \multicolumn{1}{|c|}{ Parameter name } & designation & magnitude \\
\hline Wagon weight (gross) $(\mathrm{t})$ & $G_{b}$ & 60,4 \\
\hline Wagon weight (tare) $\mathrm{t})$ & $T$ & 56 \\
\hline Design speed $(\mathrm{km} / \mathrm{h})$ & $V$ & 160 \\
\hline $\begin{array}{l}\text { Carriage length along the coupling axes of automatic } \\
\text { couplers (mm) }\end{array}$ & $2 L_{c}$ & 24536 \\
\hline Carriage base (mm) & $2 L_{t}$ & 17000 \\
\hline Distance between thrust plates of automatic couplers $(\mathrm{mm})$ & $2 L$ & 23960 \\
\hline Cart base $(\mathrm{mm})$ & $p$ & 2400 \\
\hline Dimensions in accordance with State standard 9238 & $1-T$ & \\
\hline
\end{tabular}

Evaluation of the quality of the carriage following [16] is determined by the following indicators:

- coefficients of vertical and horizontal dynamics;

- vertical and horizontal body acceleration;

- indicators of smoothness in the vertical and horizontal (transverse) directions;

- coefficient of wheel stability against derailment;

- coefficient of stability of a car against overturning in a curve under the action of lateral forces;

- coefficient of stability of a car in a train from derailment in a curve under the action of longitudinal compressive and tensile forces.

\section{Results and Discussion}

The main of the listed indicators of the quality of the carriage running are the coefficients of vertical and horizontal dynamics. 
The coefficient of vertical dynamics of the body $K_{d v}$ is determined by the formula:

$$
K_{d v}=\frac{K_{d v}^{a v}}{\beta} \cdot \sqrt{\frac{4}{\pi} \cdot \ln \frac{1}{1-P\left(K_{d v}\right)}},
$$

where $K_{d v}^{a v}$ is the average probable value of the coefficient of vertical dynamics; $\beta$ is the distribution parameter, according to [16], is taken equal to 1,$0 ; P\left(K_{d v}\right)$ is the confidence probability with which the coefficient of vertical dynamics is determined, according to [16], is 0.97 .

In this case, the average probable value $K_{d v}^{a v}$ is determined by the formula:

$$
K_{d v}^{a v}=a+3,6 \cdot 10^{-4} \cdot 8 \cdot \frac{V-15}{f_{s t}},
$$

where $a$ is coefficient, according to [16], equal to 0.05 for body elements; $B$ is coefficient that takes into account the influence of the number of axles $n$ in the bogie under one end of the carriage, equal for biaxial bogies in $6=1 ; f_{s t}$ is total static deflection of the bogie, $\mathrm{m}$.

The total static deflection of the bogie is determined by the formula:

$$
f_{s t}=f_{C}+f_{a b}
$$

where $f_{L}$ is static deflection of the central suspension stage, $\mathrm{m}$;

$f_{\bar{L}}$ is static deflection of the axle-box stage of suspension, $\mathrm{m}$;

$$
\begin{gathered}
f_{C}=\frac{P+Q_{b w}}{c_{C}}, \\
f_{b}=\frac{P+Q_{F}}{c_{a b}} .
\end{gathered}
$$

The force acting on the bogie of the car $\mathrm{P}$ is determined by the formula:

$$
P=\frac{Q_{p}}{2}+\frac{T-Q_{B}}{2},
$$

where $Q_{p}$ is mass of passengers with cargo (payload); taken according to [16] equal to $100 \mathrm{~kg}$ per passenger. Considering the population of the carriage of 44 people, we obtain $Q_{p}=4.4 \mathrm{t} ; Q_{B}$ is weights of bogies models 68-921, 68-922. According to the assembly drawings 921.00.00.000SB and 922.00.00.000SB developed by the Tashkent Plant for the Construction and Repair of Passenger Cars JSC, the bogie weights $68-921,68-922$ are taken equal to 7.4 tons and 6.8 tons, respectively; $Q_{b w}$ is bolster weight of bogies models 68-921 and 68-922. According to the assembly drawing 921.04.00.000, the safety system developed by the Tashkent Plant for the Construction and Repair of Passenger Cars JSC, the bogie bolster weight is assumed to be 0.62 tons; $Q_{F}$ is weight of the bogie frame with spintons models 68-921 and 68-922. According to the assembly drawing 
921.01.00.000SB developed by the Tashkent Plant for the Construction and Repair of Passenger Cars JSC, the mass of the bogie frame with spintons is taken to be 2.05 tons; $c_{C}$ is vertical stiffness of the springs of the central suspension of the trolley; $c_{a b}$ are vertical stiffness of the springs of axle-box suspension of the trolley.

Following the design documentation of the bogie 68-921 developed by Tashkent Plant for the Construction and Repair of Passenger Cars JSC, the vertical stiffness of the springs of the central and axle-box suspension of the bogie is $c_{C}=1466753 \mathrm{~N} / \mathrm{m}$ and $c_{a b}=4290991 \mathrm{~N} / \mathrm{m}$.

Substituting the data into formulas (6), (5), (4), (3), and (2), we obtain the calculated values of the parameters, which are summarized in table 2.

The horizontal coefficient of body dynamics $K_{d g}$ is determined by the formula:

$$
K_{d g}=\overline{K_{d g}} \sqrt{\frac{4}{\pi} \ln \frac{1}{1-P\left(K_{d g}\right)}},
$$

where $\overline{k_{d g}}$ is the average value of the coefficient of horizontal dynamics; $P\left(k_{d g}\right)$ is the confidence probability with which the coefficient of horizontal dynamics is determined, according to [16], $P\left(k_{d g}\right)=0.97$.

In this case, the average value of the horizontal dynamics coefficient is determined by the formula:

$$
\overline{K_{d g}}=8 \cdot \delta \cdot(5+v) .
$$

Where $\delta$ is the coefficient taking into account the type of running gear is taken according to [16] 0.002; $V$ is constructional speed of running, $\mathrm{m} / \mathrm{s}$.

Substituting data into formula (8), we get $\overline{K_{d g}}=0.099$.

Substituting the data into formulas (1) and (7), we obtain the coefficients of the vertical and horizontal dynamics of the passenger car body, the results of which are summarized in table 3 .

Table 2. Estimated values of the parameters of the passenger car body

\begin{tabular}{|l|c|c|}
\hline \multirow{2}{*}{ Parameter name } & \multicolumn{2}{|c|}{ Parameter value } \\
\cline { 2 - 3 } & $\begin{array}{c}\text { Taking into } \\
\text { account the } \\
\text { payload }\end{array}$ & $\begin{array}{c}\text { Excluding } \\
\text { payload }\end{array}$ \\
\hline Force acting on the carriage bogie $P(\mathrm{t})$ & 23,1 & 20,9 \\
\hline $\begin{array}{l}\text { Static deflection of the central suspension step } f_{C} \\
(\mathrm{~m})\end{array}$ & 0,161 & 0,147 \\
\hline $\begin{array}{l}\text { Static deflection of the axle-box stage of } \\
\text { suspension } f_{a b}(\mathrm{~m})\end{array}$ & 0,059 & 0,053 \\
\hline Total static deflection of the bogie $f_{s t}(\mathrm{~m})$ & 0,22 & 0,2 \\
\hline $\begin{array}{l}\text { Average probable value of the coefficient of } \\
\text { vertical dynamics: } \\
\text { - in the second design mode: } \\
\text { - in the third design mode: }\end{array}$ & $\begin{array}{c}0,05 \\
0,101\end{array}$ & 0,05 \\
\hline
\end{tabular}


Table 3. Dynamic qualities of a passenger car

\begin{tabular}{|l|c|c|}
\hline \multicolumn{1}{|c|}{ Parameter name } & Calculated value & $\begin{array}{c}\text { Highest allowable } \\
\text { value }\end{array}$ \\
\hline $\begin{array}{l}\text { Vertical body dynamics coefficient } K_{d v} \\
\text { in the second design mode: }\end{array}$ & 0,106 & \\
- taking into account the payload & 0,106 & 0,35 \\
- without payload & 0,211 & 0,35 \\
in the third design mode: & 0,216 & 0,35 \\
- taking into account the payload & 0,21 & 0,35 \\
- without payload & & 0,25 \\
\hline Horizontal dynamics coefficient of the body & & \\
$K_{d g}$ & \\
\hline
\end{tabular}

The rest of the quality indicators of the carriage running were determined in the same way.

\section{Conclusions}

According to the results of theoretical studies, it was found that the quality indicators of the passenger carriage model 61-920 do not exceed the permissible values and meet the requirements [16]. Based on the positive results of theoretical studies, a prototype of this car was built. Experimental studies were carried out according to the requirements [12-15] and to check the selected parameters of the passenger carriage. The comparative analysis of the results of theoretical and experimental studies showed their good convergence, based on which it can be concluded that the designed carriage has high-quality performance, which creates favorable comfortable conditions for passengers on the way.

\section{References}

1. Rahimov R V, Choice of directions for the development of the wagon fleet of Uzbekistan railways Transport of the Russian Federation 1 (74) pp 71-74. (2018)

2. Rahimov R V, Ruzmetov $\mathrm{Ya} \mathrm{O}$, Analysis of the state and prospects of the development of the freight wagon fleet of the Republic of Uzbekistan NonFerrous Metals. 44 (1) pp 7-11. (2018)

3. Rahimov R V, State and prospects for the development of the wagon fleet of railways in Uzbekistan Proc. Materials of the XIII International Scientific and Technical Conference "Rolling stock of the XXI century: ideas, requirements, projects" (Saint Petersburg: Emperor Alexander I St. Petersburg State Transport University) pp 124-128. (2018).

4. Boronenko Yu P, Rahimov R V, Assessment of the need for new passenger cars for the railways of Uzbekistan and the main directions of their improvemen, $t$ Bulletin of Tashkent Institute of Railway Engineering (2) pp 88$91(2009)$

5. Rasulov M. Kh, Ibragimov U. N, Rahimov R. V, Problems of increasing the competitiveness of domestic railway corridors Proc. Scientific works of the Republican scientific and technical conference with the participation of foreign 
scientists "Resource-saving technologies in railway transport" (Tashkent: Tashkent Institute of Railway Engineering) pp 14-17. (2013).

6. Rahimov R V, Galimova F S, Introduction of modern technologies in the enterprise SJSRC O'zbekiston temir yo'llari, Bulletin of Tashkent State Technical University (3) pp 159-164 (2015).

7. Rahimov $\mathrm{R} \mathrm{V}$, The first Uzbek long-distance passenger carriage Heavy Engineering. (6) pp 34-35 (2010)

8. Rahimov R V, Khokhlov S V, New bogies for passenger cars produced by the Tashkent plant for the construction and repair of passenger cars, Proceedings of Petersburg Transport University, (3) pp 157-165 (2010)

9. Minovarov R M, Rahimov R V, Passenger cars built by the Republic of Uzbekistan Bulletin of Tashkent Institute of Railway Engineering, (3-4) pp 40452009

10. Rahimov R V, Development of a new passenger carriage for the railways of Uzbekistan Materials of the VI International Scientific and Technical Conference, "Rolling stock of the XXI century: ideas, requirements, projects" (Saint Petersburg: Emperor Alexander I St. Petersburg State Transport University) pp 150-153. (2009)

11. Rahimov R V, Khokhlov S V, Improvement of the design of a passenger trolley with cradle suspension for models 68-909 and 68-908 Materials of the VI International Scientific and Technical Conference, "Rolling stock of the XXI century: ideas, requirements, projects" (Saint Petersburg: Emperor Alexander I St. Petersburg State Transport University) pp 204-205. (2009).

12. Rahimov R N, New compartment-type passenger carriage for the railways of Uzbekistan Proceedings of Petersburg Transport University, (2) pp 286-295. (2010)

13. Rahimov R V, Evaluation of the running characteristics of a new passenger carriage model 61-920 manufactured in the Republic of Uzbekistan Proc. Problems of Mechanics, (2) pp 53-56, (2015).

14. Rahimov R V, Undercarriage parts of cars (Tashkent: Uzbekistan) p 200 (2018).

15. Rahimov R V, Wagons (Tashkent: Tashkent Institute of Railway Engineering) $\mathrm{p} 180,(2018)$

16. GOST 55182-2012. Locomotive-hauled passenger cars. General technical requirements. - Introduction 01.01.2014 (Moscow: Standartinform) p 27

17. OST 24.050.16-85. Passenger cars. Method for determining the smoothness of the course. - Introduction 01/01/1987 p 14.

18. Standards for the calculation and design of new and modernized carriages of $1520 \mathrm{~mm}$ track gauge railways of the Ministry of Railways (non-selfpropelled,) (Moscow: VNIIV VNIIZhT, 1983) p 260. (1983). 